records of natural products

\title{
Silybum marianum: not Just Silymarin and Flavonolignans
}

\section{Maria Giordano $\oplus^{* 1}$, Giovanni Luongo $\oplus^{2}$, Sergio Davinelli ${ }^{3}$, Afef Ladhari ${ }^{4}$, Giuseppina Rita Nappo ${ }^{5}$ and Maddalena Giordano ${ }^{2}$}

\author{
${ }^{1}$ Department of Agricultural Sciences, University Federico II, 80055 Portici, Italy \\ ${ }^{2}$ Department of Chemical Sciences, University Federico II, Via Cinthia 4, 80126 Napoli, Italy \\ ${ }^{3}$ Department of Epidemiology, Harvard T.H. Chan School of Public Health, Boston, MA 02115, \\ United States \\ ${ }^{4}$ Université de Carthage, Institut National Agronomique de Tunisie (INAT), Laboratoire GREEN- \\ TEAM (LR17AGR01), 43 Avenue Charles Nicolle, 1082 Tunis, Tunisie. \\ ${ }^{5}$ Associazione Italiana per la Promozione delle Ricerche su Ambiente e Salute umana, 82030 -
}

Dugenta, BN, Italy

(Received September 30, 2020; Revised December 15, 2020; Accepted December 16, 2020)

\begin{abstract}
The use of Silybum marianum L. for therapeutic purposes has been known since ancient times. Its phytocomplex reduces transaminases and other biohumoral indices in the course of liver disease and also in hepato-renal syndrome. In particular, the flavonolignan component has shown properties that would partially explain the ability of the phytocomplex to induce a certain regeneration of liver cells, stimulate the cellular elimination of toxins and reduce the inflammatory component, present in fatty, alcoholic and hormonal therapies with steroids. S. marianum is also successfully used in the treatment of patients with symptomatic chronic hepatitis, with complete disappearance of clinical symptoms, such as asthenia, loss of appetite, severe meteorism, dyspepsia, and with normalization of transaminases. The same results can be obtained in patients undergoing heavy chemotherapy cycles. Modern herbal medicine uses it in decoction or infusion, however with some caution in patients suffering from hypertension, due to the presence of tyramine. In addition, the extracts of the roots have antioxidant, diuretic and febrifugal properties and those of the leaves have aperitif properties. It is therefore interesting to provide a picture of the different non-flavonolignanic components (terpenes, steroids and essential oils) of the plant and their properties, which have perhaps been wrongly neglected over the past few years.
\end{abstract}

Keywords: Silybum marianum; natural substances; silibinin; terpenes; steroids; biological activities. @ 2021 ACG Publications. All rights reserved.

\section{Introduction}

Plants can provide bioactive compounds, generally secondary metabolites or even simple waste products of their metabolism [1]. In this regard, the study of phytotoxic activity of natural substances

*Corresponding author: E- Mail: maria.giordano@unina.it 
plays an important role in the research of new eco-compatible active compounds to limit the proliferation of weeds, with undoubted advantages related to the identification of new chemical structures [2,3] that usually are quite difficult or impossible to obtain by synthesis [4-6]. Many reports highlighted as the study of substances from natural origin can facilitate the design for the synthesis of new molecules with phytotoxic activity [7-9], and increase the discovery of substances with sites and mechanisms of action different from those of synthetic herbicides aiming at a greater environmental safety [10-14]. But, during the last years, the use of natural products, pure or in mixture, has increased for food, voluptuous, aesthetic or therapeutic purposes, too [15]. In the continuous scientific research of new safe and effective drugs, there has been a rediscovery of natural substances as a potential reservoir of innovative therapeutic solutions for human health with the prospect of integrating and sometimes replacing conventional drugs [16,17]. Milk thistle is a wild herbaceous plant typical of the Mediterranean regions where it grows spontaneously in almost all climates and latitudes adapting to any type of soil. Usually, this plant is not the object of massive cultivation and can be a pest, only in few areas where the thistle is cultivated. The seeds are collected and subjected to a mechanical shaking action to encourage the distribution and growth of new plants. The plant is made up of a rose of thorny leaves. The flowers, which reach maturity in summer, are red-purple, while the fruits are oblong achenes of bright black color, stained with yellow. In practice, these are dried fruits that contain only one seed. The milk thistle belongs to the Plantae kingdom, of the Asterales order belonging to the Asteraceae family. The genus is the Silybum and the species is called marianum. It was first classified by Carl von Linné. In a second time, the milk thistle was reclassified by the German botanist Joseph Gaertner in his main work "De Fructibus et Seminibus Plantarum". In botany, the milk thistle has many synonyms: Carduus marianus, Centaurea dalmatica, Silybum mariae, Silybum marianum albiflorum, Silybum pygmaeum, Silybum maculatum, Silybum marianum longispina, Silybum leucanthum and Mariana lactea. The history of the milk thistle has very ancient origins, even the ancient Greeks knew its properties, in fact they used it in mixture with honey as a natural remedy for cough treatment. Its use has continued over the centuries widening also for the cure of other diseases related to the respiratory tract. In the Middle Ages, cultivation began mainly within monasteries and from this point on, many specific studies followed. Already in the mid-1700s the beneficial properties of the milk thistle against the liver were documented by the Swiss scientist Albrecht Von Haller, and subsequently were confirmed by medical scholars who extended the beneficial properties also to the spleen and the bile duct. The fruits produced an extract named silymarin that consist of a set of flavolignans concentrated in the outer protein layer of the fruit [18]. The main components of silymarin are silibinin, isosilybins, silicristin and silidianin [19]. Hepatoprotective action and efficacy in the treatment of degenerative liver diseases, such as cirrhosis, hepatitis $\mathrm{C}$ or liver disease caused by alcohol abuse or cardo drugs, has been confirmed by numerous scientific studies. The hepatoprotective activity is mainly due to the ability of silymarin as inhibitor of fat peroxidation, as regulator of cellular permeability and, more generally, as inhibitor of the formation of metabolites responsible for hepatic damage [20]. Of the flavonolignans present in silymarin to date the attention has been focused mostly on silibinin, the most abundant component that consists of a mixture of diastereoisomers silybin A and B, which are very difficult to be separated [21]. However, the use of silibinin is limited by its low solubility in water $(0.4 \mathrm{mg} / \mathrm{L})$ [22] that involves also in a low bioavailability [23,24]. Several research groups are involved in solving these problems using a pro-drug approach with the insertion of phosphate groups that considerably increases the water solubility of drug [25-27] or through the use of liposomes [28]. In addition to silymarin, the fruit contains other active substances with a protective action such as flavonoids, antioxidants, proteins, oleic, and linolenic acids, but above all sterols. Plant sterols, essential fatty acids and flavonoids play an effective protective action against cardiovascular diseases [29]. The protective and antioxidant effect is clearly enhanced by silibinin, which prevents fat oxidation and damage to cell membranes. Recent scientific research has confirmed that the silibinin could also be effective as a protector against some types of cancer, cardiovascular or renal diseases and Alzheimer disease [30,31]. Today it has been discovered that milk thistle also benefits many other organs, strengthens the capillaries, counteracts the action of free radicals, regulates blood pressure, and promotes intestinal regularity [32]. The plant is a vital remedy in case of mushroom poisoning, it is also recognized for its tonic and decongestant properties that can benefit people suffering from depression, food allergies and chronic fatigue problems, and is used in patients who are subjected to chemotherapy regarding to the purifying and detoxifying properties of its active principles. As a 
natural remedy, milk thistle can be found in pharmacies, herbal medicine and organic stores in various formulations, including mother tincture, capsules, powder, liquid extracts, and decoction obtained from the extracts of the dry plant. The milk thistle is a well-tolerated herbal medicine and up to now it has no contra-indications. Adverse effects are rare, of mild intensity and of a gastrointestinal type. The majority of recently published reviews on the milk thistle mainly reported the chemistry and pharmacology studies on the silymarin extract. Conversely, this work aims to examine in depth the chemical composition of milk thistle keeping out the silymarin extract and reporting indeed the isolation and identification of the less abundant components of plant as terpenes and steroids with relative biological activities.

\section{Extraction and Isolation of Mono and Sesquiterpenes}

Recent papers have reported the abundance in terpenes of the seeds of milk thistle, and have highlighted their role as natural preservatives which can replace synthetic additives in a myriad of food products and not, thus preserving both health and environment $[33,34]$. In particular, the seeds were extracted with a Soxhlet extractor using $n$-hexane and then ethanol, for 6 hours (Scheme 1).

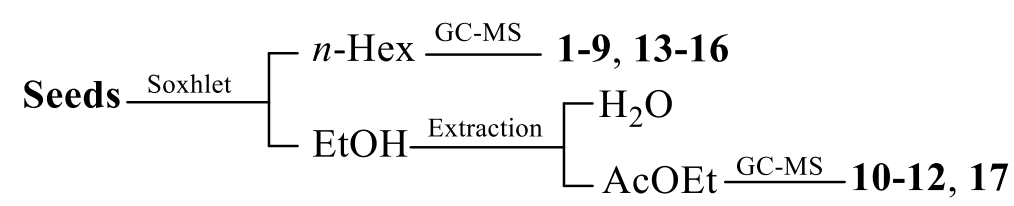

Scheme 1. Fractionation scheme of Soxhlet seed extracts

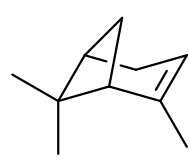

$\alpha$-Pinene (1)<smiles>CC1=CCC(C(C)C)=CC1</smiles>

$\gamma$-Terpinene (7)

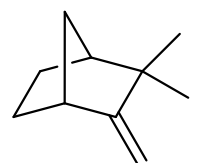

Canfene (2)<smiles>C=CC(C)(O)CCC=C(C)C</smiles>

Linalool (3)<smiles>C=C(C)[C@H]1CC=C(C)CC1</smiles>

Limonene (4)

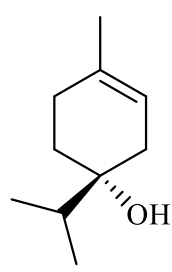

Terpinene-4-ol (5)<smiles>CC1=CCC(C(C)(C)O)CC1</smiles>

$\alpha$-Terpineol (6)<smiles>Cc1ccc(C(C)(C)O)cc1</smiles>

P-cymene-8-ol (9)<smiles>CC(C)(O)c1ccc(CO)c(O)c1</smiles>

$10 \mathrm{R}=\mathrm{H}$

$11 \mathrm{R}=\beta-\mathrm{D}-\mathrm{Glc}$ Mariaterpenoside $\mathrm{A}$<smiles>Cc1ccc([C@@H](C)CO)cc1O</smiles>

12

Figure 1. Monoterpenes isolated from Soxhlet seed extracts 
<smiles>C=C1CC[C@H](C(C)C)[C@H]2C=C(C)CC[C@H]12</smiles>

$\gamma$-Cadinene (13)<smiles>C=C(/C=C/[C@H](CC/C(C)=C/C)C(C)C)CC</smiles>

Germacrene D (14)

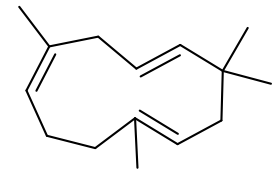

$\alpha$-Caryophyllene (15)<smiles>C=C1CC/C=C(/C)CC[C@@H]2[C@@H]1CC2(C)C</smiles>

$\beta$-Caryophyllene (16)<smiles>CC1=C2C[C@H](C(C)(O)CO)CC[C@]2(C)[C@H](O)CC1=O</smiles>

Hydroxyanhuienosol (17)

Figure 2. Sesquiterpenes isolated from Soxhlet seed extracts

All analyses were carried out by Gas Chromatography-Mass Spectrometry (GC-MS), the extract with $n$-hexane showed the presence of monoterpenes 1-9 (Figure 1) and sesquiterpenes 13-16 (Figure 2 ), together in amounts equal to $0.12 \%$ of the dry weight of the plant [33].

Sesquiterpenes 13-16 constitute 55\% of the extract and compounds 13 and 15 are the most abundant, with percentages of about 50 and $4.5 \%$, respectively. The monoterpenes are less abundant (39\%) and between them hydrocarbons $\mathbf{1}, \mathbf{2}, \mathbf{4}, \mathbf{7}$ and $\mathbf{8}$ are slightly more than $33 \%$, in particular compound 1 with a percentage of $24.5 \%$, while the oxygenated $3,5,6$ and 9 are about $6 \%$. Other components have been highlighted but not identified. The ethyl acetate fraction of ethanol extract contained the monoterpenes 10-12 (Figure 1) and sesquiterpene $\mathbf{1 7}$ (Figure 2), that were identified by comparison with reference compounds [34].

\section{Steroids and Triterpenes}

Regarding the determination of steroids and triterpenes, compounds $18,23,31,36-42$ and $45-48$ were isolated from the alcoholic extracts, obtained by infusion, of the whole plant (Figure 3a and 3b; Table 1). In particular, the methanolic extract was concentrated under reduced pressure to obtain a rubbery material which was then freeze-dried. The dried crude material was extracted in succession with petrol ether, chloroform, ethyl acetate, $n$-butanol and water (Scheme 2).

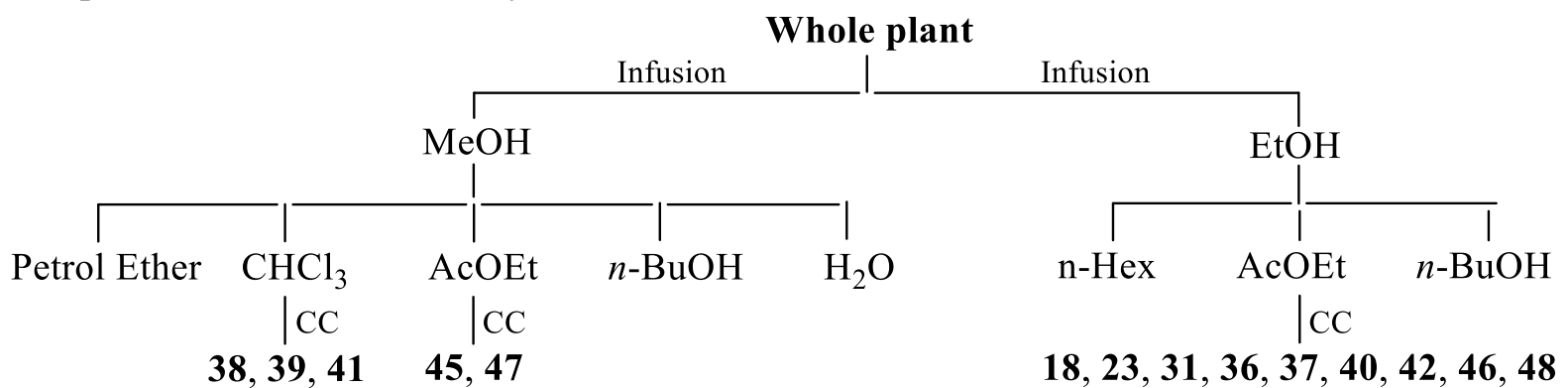

Scheme 2. Fractionation scheme of alcoholic extracts of whole plant

The chloroform extract was subjected to the Salkowski test which highlighted the presence of terpenes [3,35]. From this extract the compounds 38, 39 and $\mathbf{4 1}$ were isolated and identified, interestingly these compounds represent the first lanostane-type triterpenes isolated from milk thistle [36]. The compounds silymin B (45) and silymin A (47) were isolated from the ethyl acetate extract, that gave positive Liebermann-Burchard test (acetic anhydride-conc. $\mathrm{H}_{2} \mathrm{SO}_{4}$ ) with the formation of a blue-green colour which highlighted the presence of triterpenes [37]. The ethanolic extract obtained by infusion was concentrated under reduced pressure to obtain a rubbery material which was then freezedried. The dried material was extracted in succession with $n$-hexane, ethyl acetate and $n$-butanol. From the soluble fraction of ethyl acetate, the compounds $18,23,31,36,37,40,42,46$, and 48 [38] were isolated. 


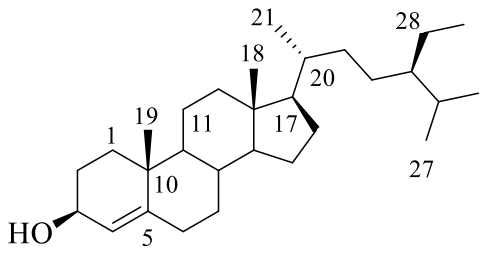

18<smiles>C=C(C)[C@H](CC)CC[C@H](C)[C@H]1CCC2C3CC=C4C[C@@H](O)CC[C@]4(C)C3CC[C@]21C</smiles>

24<smiles>CCC(CC[C@@H](C)[C@H]1CCC2C3=CCC4C[C@@H](O)CC[C@]4(C)C3CC[C@]21C)C(C)C</smiles>

28<smiles>CCC(/C=C/[C@H](C)[C@H]1CCC2C3=CC=C4C[C@@H](O)CC[C@]4(C)C3CC[C@]21C)C(C)C</smiles>

32<smiles>C/C=C(/CC[C@H](C)[C@H]1CCC2C3=CC[C@H]4[C@@H](C)[C@H](O)CC[C@]4(C)C3CC[C@]21C)C(C)C</smiles>

35

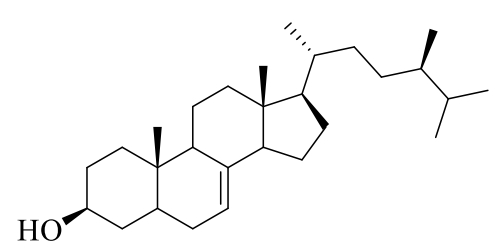

19

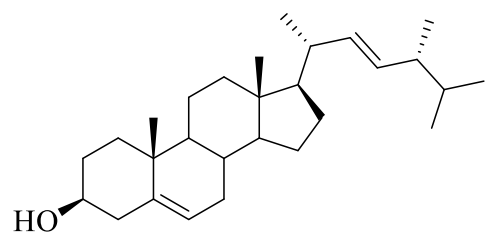

25

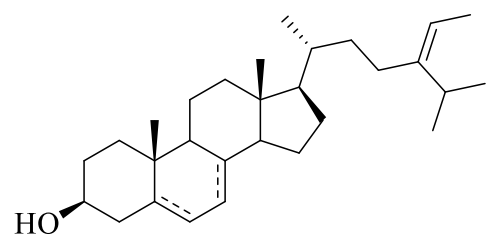

$29 \Delta^{5}$

$30 \Delta^{7}$

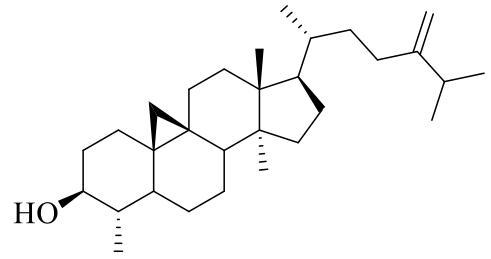

33

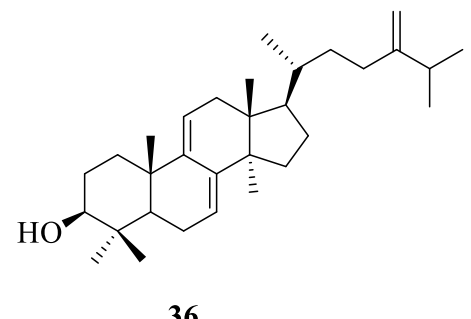

Figure 3a. Steroids 18-37 isolated by milk thistle 


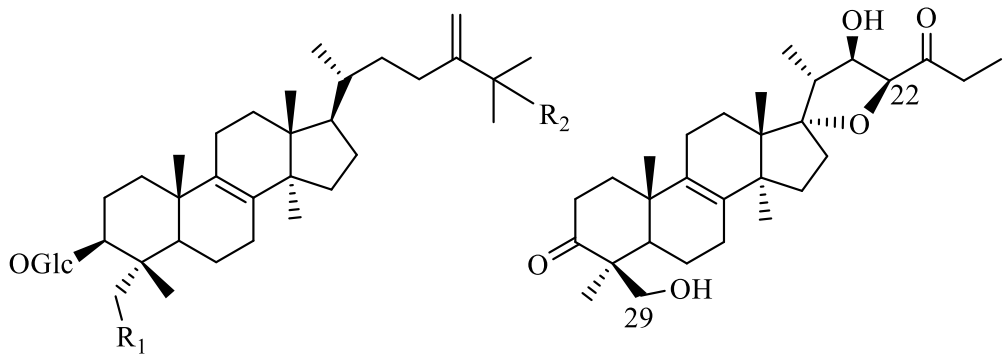

$38 \quad \mathbf{R}_{\mathbf{1}}=\mathbf{R}_{\mathbf{2}}=\mathrm{H}$

$39 \mathbf{R}_{\mathbf{1}}=\mathbf{R}_{\mathbf{2}}=\mathrm{OH}$<smiles></smiles>

42

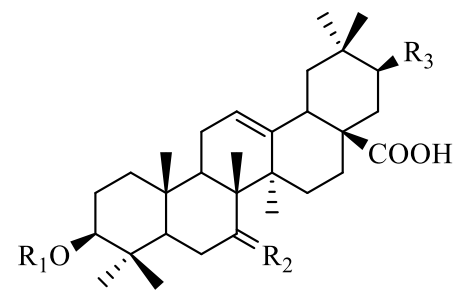

$\begin{array}{llll}\mathbf{4 5} & \mathbf{R}_{\mathbf{1}}=\mathrm{H} & \mathbf{R}_{\mathbf{2}}=\mathrm{O} & \mathbf{R}_{\mathbf{3}}=\mathrm{OH} \\ \mathbf{4 6} & \mathbf{R}_{\mathbf{1}}=\mathrm{COCH}_{3} & \mathbf{R}_{\mathbf{2}}=\mathrm{H}_{2} & \mathbf{R}_{\mathbf{3}}=\mathrm{H}\end{array}$<smiles>CC(C)=CCC[C@H](C)[C@H]1CC[C@]2(C)C3CCC4C(C)(C)[C@@H](O)CC[C@]45C[C@]35CC[C@]12C</smiles>

43

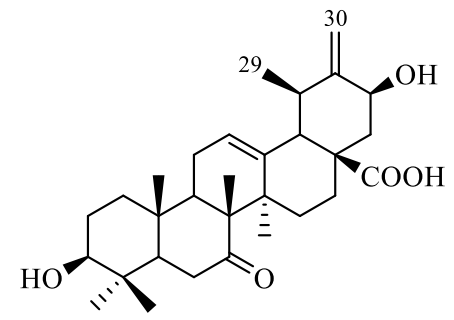

47<smiles>C=C(CC[C@H](C)[C@H]1CC[C@]2(C)C3=C(CC[C@]12C)[C@@]1(C)CC[C@H](O)C(C)(C)C1CC3=O)C(C)(C)O</smiles>

41

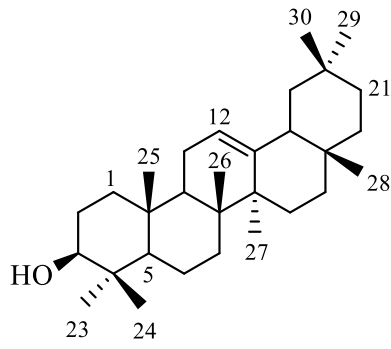

44

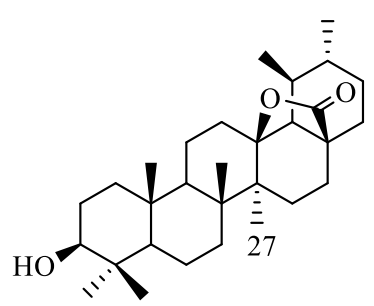

48

Figure 3b. Steroids 38-48 isolated milk thistle

Compounds 19-22, 24-30, 32-35, and 43-44 were isolated from the seeds of S. marianum particularly rich in steroids ((Figures 3a and 3b; Table 1). From the Soxhlet extract with $n$-hexane, just over $6.2 \mathrm{~g} / \mathrm{kg}$, desmethylsterols 20-22, 26 and, 28-30 [39,40] were isolated and identified by GC-MS analyses. The most abundant was $\beta$-sitosterol 22 , up to $27 \%$, an interesting fact considering that this results in a decrease in the absorption of dietary cholesterol [41].

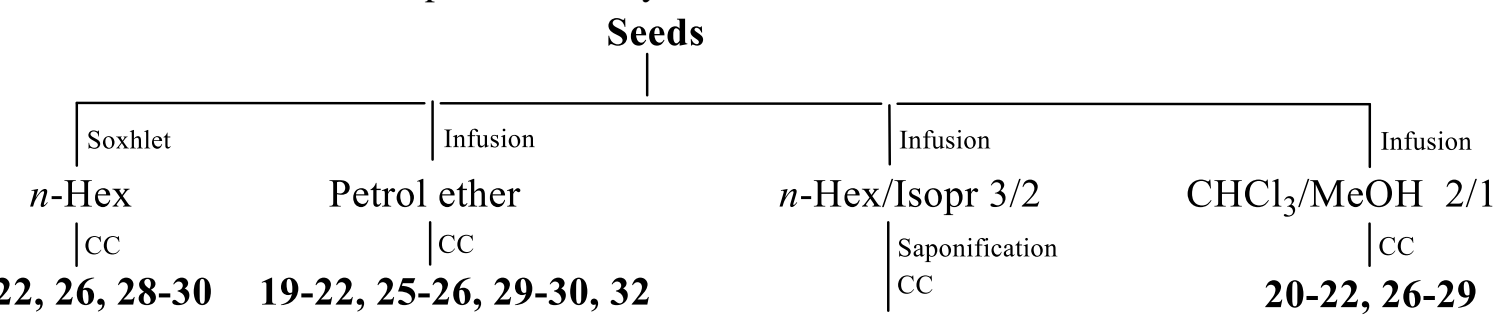

$$
\text { 24, 33-35, 42-44 }
$$

Scheme 3. Fractionation scheme of infusions by seeds.

Compounds 19-22, 25-26, 29-30, and 32 were isolated from the infusion obtained with petrol ether (Scheme 3) [42]. From the infusion with $n$-hexane/isopropanol 3:2, slightly more than $2.3 \mathrm{~g} / \mathrm{kg}$ has been obtained after saponification and its components have been identified by GC-MS analysis [43]. In particular, it has been isolated and identified compound 24, some 4-monomethylsterols 33-35, 
and among these the most abundant was the compound 35, in addition to 4,4'-dimethylsterols $\mathbf{4 2 - 4 4}$, of which the $\mathbf{4 2}$ is the most abundant [44]. Finally, the compounds 20-22 and 26-29 were isolated from the infusion obtained with $\mathrm{CHCl}_{3} / \mathrm{MeOH}$ 2:1 [45].

Table 1. Steroids isolated from S. marianum.

\begin{tabular}{|c|c|c|c|}
\hline No. & Common name & Systematic name & CAS Number \\
\hline 18 & $\beta$-Rosasterol & Stigmast-4-en-3- $\beta$-ol & $134876-41-8$ \\
\hline 19 & $\Delta^{7}$-Campesterol & $3 \beta, 24 R$-Ergost-7-en-3-ol & 70095-94-2 \\
\hline 20 & Cholesterol & $\Delta^{5}$ Cholesten-3 $\beta$-ol & $57-88-5$ \\
\hline 21 & Campesterol & 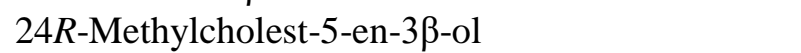 & $474-62-4$ \\
\hline 22 & $\beta$-Sitosterol & $24 R$-Ethylcholest-5-en-3 $\beta$-ol & $83-46-5$ \\
\hline 23 & $\begin{array}{l}\beta \text {-Sitosterol 3-O- } \beta \text {-D- } \\
\text { xylopyranoside }\end{array}$ & $3 \beta$-Stigmast-5-en-3-yl $\beta$-D-xylopyranoside & 93772-33-9 \\
\hline 24 & Cleroesterol & Stigmasta-5,25-dien-3 $\beta$-ol & $2364-23-0$ \\
\hline 25 & Brassicasterol & Ergosta-5,22-dien-3 $\beta$-ol & $474-67-9$ \\
\hline 26 & Stigmasterol & Stigmasta-5,22-dien-3 $\beta$-ol & $83-48-7$ \\
\hline 27 & Spinasterol & $5 \alpha$-Stigmasta-7,22-dien-3 $\beta$-ol & $481-18-5$ \\
\hline 28 & $\Delta^{7}$-Stigmastenol & Stigmast-7-en-3 $\beta$-ol & $6869-99-4$ \\
\hline \multirow[t]{2}{*}{29} & $\Delta^{5}$-Avenasterol/ & 3ß-Stigmasta-5,24(28)-dien-3-ol/ & $18472-36-1 /$ \\
\hline & Isofucosterol & $3 \beta, 24 Z$-Stigmasta-5,24(28)-dien-3-ol & $481-14-1$ \\
\hline 30 & $\Delta^{7}$-Avenasterol & $3 \beta, 5 \alpha, 24 Z$-Stigmasta-7,24(28)-dien-3-ol & $23290-26-8$ \\
\hline 31 & 22-Dehydroclerosterol & 24S-24 Ethyl cholesta-5,22E,25-triene-3 $\beta$-ol & $26315-07-1$ \\
\hline 32 & $\Delta^{7}$-Stigmasterol & Stigmasta-5,7,22-trien-3 $\beta$-ol & $481-19-6$ \\
\hline 33 & Cycloeucalenol & $4 \beta$-Demethyl-24-methylenecycloartanol & $469-39-6$ \\
\hline 34 & Obtusifoliol & $3 \beta, 4 \alpha, 5 \alpha-4,14$-Dimethylergosta-8,24(28)-dien-3-ol & $16910-32-0$ \\
\hline 35 & Citrostadienol & $\begin{array}{l}3 \beta, 4 \alpha, 5 \alpha, 24 Z-4-M e t h y l s t i g m a s t a-7,24(28) \text {-dien-3- } \\
\text { ol }\end{array}$ & $474-40-8$ \\
\hline 36 & 24-Methyleneagnosterol & 24-Methylenelanosta-7,9(11)-diene-3- $\beta$-ol & $35624-74-9$ \\
\hline 37 & Polyporenic acid C & $\begin{array}{l}\text { Lanosta-7,9(11)-dien-21-oic acid, 16 } \alpha \text {-hydroxy- } \\
\text { 24-methylene-3-oxo }\end{array}$ & $465-18-9$ \\
\hline 38 & Marianoside B & 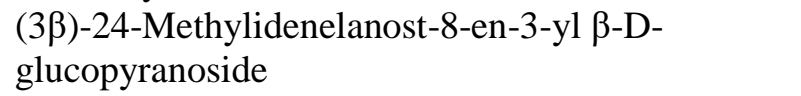 & $886437-21-4$ \\
\hline 39 & Marianoside A & $\begin{array}{l}\text { 24-Methylene-lanoesta-89-ene-25,28-diol 3-O- } \beta \text { - } \\
\text { D-glucopyranoside }\end{array}$ & $886437-20-3$ \\
\hline 40 & - & $\begin{array}{l}\text { 22R,23S-17 } \alpha, 23 \text {-Epoxy-22,29-dihydroxy-27- } \\
\text { norlanost-8-en-3,24-dione }\end{array}$ & $713124-66-4$ \\
\hline 41 & Marianine & $\begin{array}{l}\text { (3ß)-3,25-Dihydroxy-24-methylene-lanost-8-en-7- } \\
\text { one }\end{array}$ & $886437-19-0$ \\
\hline 42 & 24-Methylencycloartanol & 3ß-24-Methylene-9,19-cyclolanostan-3-ol & $1449-09-8$ \\
\hline 43 & Cycloartenol & Cycloart-24-en-3 $\beta$-ol & $469-38-5$ \\
\hline 44 & $\beta$-Amyrin & Olean-12-en-3 $\beta$-ol & $559-70-6$ \\
\hline 46 & Oleanolic acid 3 -acetate & 3ß-3-Acetyloxyolean-12-en-28-oic acid & $4339-72-4$ \\
\hline 45 & Silymin B & $\begin{array}{l}3 \beta, 21 \beta-3,21 \text {-Dihydroxy-7-oxo-olean-12-en-28-oic } \\
\text { acid }\end{array}$ & $926307-53-1$ \\
\hline 47 & Silymin A & 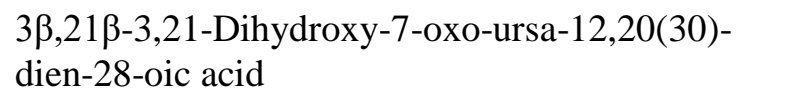 & $926307-51-9$ \\
\hline 48 & - & 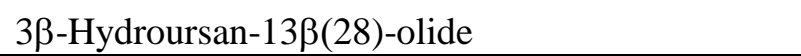 & $29428-70-4$ \\
\hline
\end{tabular}

\subsection{Biological Effects of Terpenes and Steroids Isolated by S. marianum}

Only a few sesquiterpenes isolated from the milk thistle were tested to evaluate some biological properties. In particular, it has been assessed the ability to inhibit the production of LPS-induced nitric oxide NO in murine microglial cells BV-2 of compounds 10-12 and 17 [34]. The results showed that 
the $\mathrm{IC}_{50}(7,15,14,18 \mu \mathrm{M}$ respectively) were slightly higher than the value of the 2-methylthiopseudourea sulfate used as a reference; even more interesting, these compounds did not show significant cytotoxicity by MTT test at the concentrations used. Moreover, studies of molecular docking showed their strong interaction with the inducible nitric oxide synthase, responsible for the synthesis of NO during inflammatory processes that plays an important role in degenerative processes contributing to the neuronal death [34].

The terpenoids $18,23,31,36,40,42,46$ and 48 were tested for the determination of antifungal activity on Candida glabrata, Candida albicans, Microsporum canis, Fusarium solani, Trichophyton longifusus and Aspergillus flavus, using Miconazole (M) and Amphotericin B (AB) as a reference standard [38] (Table 2).

Table 2. Antifungal activity of compounds 18, 23, 31, 36, 40, 42, 46 and 48 in agar tube dilution method

\begin{tabular}{lcccccccccccc}
\hline Fungal species & $\mathbf{1 8}$ & $\mathbf{2 3}$ & $\mathbf{3 1}$ & $\mathbf{3 6}$ & $\mathbf{3 7}$ & $\mathbf{4 0}$ & $\mathbf{4 2}$ & $\mathbf{4 6}$ & $\mathbf{4 8}$ & M & AB & Ref. \\
\hline T. longifusus & + & - & + & ++ & ++ & ++ & - & - & ++ & 70 & & \\
C. glabrata & ++ & - & - & ++ & ++ & ++ & - & - & ++ & 110.8 & & \\
F. solani & ++ & - & + & + & ++ & + & - & - & - & 73.25 & & 38 \\
C. albicans & - & - & + & ++ & + & + & - & - & + & 110 & & \\
M. canis & - & - & + & + & + & - & - & - & - & 98.4 & & \\
A. flavus & ++ & - & - & - & + & - & - & - & - & & 20 & \\
\hline
\end{tabular}

- Values of inhibition of radial growth $<50 \%$; + values of inhibition of radial growth $>50$ and $<74 \%$; ++ values of inhibition of radial growth $>75 \%$. Miconazole (M) and Amphotericin B (AB)

Compounds 23, 42 and 46 are very poorly active on fungal species, while the other ones are moderately active, especially compounds 48, 40, 18, 36 and 37 on T. longifusus and C. glabrata. Hepatitis $\mathrm{C}$ virus HCV infection is one of the primary causes of chronic hepatitis, cirrhosis and hepatic carcinoma. In the NS protein group, the Chymotrypsin like serine protease known as NS3 appears to be the most promising target for new antiviral drugs. Compounds 38, 39 and $\mathbf{4 1}$ were tested in vitro to evaluate their ability to inhibit Chymotrypsin, by spectrophotometric test using as substrate $\mathrm{N}$ succinyl-phenylalanine-p-nitroanilide and monitoring the reaction at $410 \mathrm{~nm}$ with Chymostatin used as a reference. In general, proteases such as chymotrypsin have a fundamental role in the defense against pathogens and can cause damage to the digestive tract also fatal of certain insects. The compounds tested are able to inhibit the hydrolysis of the Chymotrypsin by $50 \%$ at concentrations ranging from 9.4 to $28.2 \mu \mathrm{M}$. Compound $\mathbf{4 1}$ was the most active of the three, with an $\mathrm{IC}_{50}$ value almost equal to that of Chymostatin used as a reference. The results confirm the preliminary tests on the methanolic extract that showed a strong toxicity in the brine shrimp lethality and, in particular, the chloroform-soluble fraction from which the compounds 38, $\mathbf{3 9}$ and $\mathbf{4 1}$ were isolated, showed a significant inhibitory activity against the enzyme chymotrypsin [37].

\section{Conclusions}

The beneficial properties of milk thistle in the treatment of liver disorders have long been known by folk medicine, which uses fruits and leaves of the plant. In fact, over the last 30 years a huge number of articles have been published focusing on silymarin, a complex mixture of flavonolignans, and on its individual components, highlighting their activities and limits. The milk thistle is also used as an antidote for poisoning with mushrooms of the genus Amanita and homeopathic medicine uses it in case of jaundice, biliary colic, hepatitis, stomach ache, peptic ulcers and venous circulatory insufficiency. However, there is not a general framework on the other classes of compounds isolated from this plant, primarily terpenoids and steroids, of which an insufficient and incomplete picture of biological activities has been defined. This work examines in depth the potentialities of milk thistle, reporting the identified terpenes and steroids extracted by the plant and their biological activities. Even if there are very few data performed determining the fungicidal and larvicidal efficacy of terpenoids, it is well known that essential oils exert an antimicrobial action and/or antifungal, at least to certain 
species. Concerning terpenes isolated from milk thistle, it has been reported that the triterpenes, present in essential oils act as antifungals up to concentrations of 5-25 ppm. So, the mixture of terpenoids and steroids and their possible synergistic effects could delineate interesting applications in the food, nutraceutical, and even pharmacological fields.

\section{Acknowledgments}

This study was supported by AIPRAS Onlus Associazione Italiana per la Promozione delle Ricerche sull'Ambiente e la Salute umana.

\section{Author Contributions}

All authors contributed to the draft of the article and approved the final manuscript.

\section{Conflicts of Interest}

The authors declare no conflict of interest.

\section{ORCID}

Maria Giordano: 0000-0001-5463-3768

Giovanni Luongo: 0000-0002-8308-9682

Sergio Davinelli: 0000-0003-2578-7199

Giuseppina Rita Nappo: 0000-0003-1883-6132

Afef Ladhari: 0000-0001-8906-5748

Maddalena Giordano: 0000-0002-3537-477X

\section{References}

[1] F. Lelario, L. Scrano, S. De Franchi, M. G. Bonomo, G. Salzano, S. Milan, L. Milella and S. A. Bufo (2018). Identification and antimicrobial activity of most representative secondary metabolites from different plant species, Chem. Biol. Technol. Agric. 51, 13-24.

[2] F. Cutillo, M. Della Greca, M. Gionti, L. Previtera and A. Zarrelli (2006). Phenols and lignans from Chenopodium album, Phytochem. Anal. 17, 344-349.

[3] M. Della Greca, A. Fiorentino, P. Monaco, L. Previtera and A. Zarrelli (1995). Effusides I-V: 9,10dihydrophenanthrene glucosides from Juncus effuses, Phytochemistry 40, 533-535.

[4] S. C. Heredia-Vieira, A. M. Simonet, W. Vilegas and F. A. Macías (2014). Unusual C, O-fused glycosylapigenins from Serjania marginata leaves., J. Nat. Prod. 781, 77-84.

[5] M. Della Greca, A. Fiorentino, P. Monaco, L. Previtera, F. Temussi and A. Zarrelli (2003). New dimeric phenanthrenoids from the rhizomes of Juncus acutus. Structure determination and antialgal activity, Tetrahedron 59, 2317-2324.

[6] M. Della Greca, A. Fiorentino, P. Monaco, L. Previtera and A. Zarrelli (2002). A new dimeric 9,10dihydrophenanthrenoid from the rhizome of Juncus acutus, Tetrahedron Lett. 43, 2573-2575.

[7] A. Santana, J. M. Molinillo and F. A. Macías (2015). Trends in the synthesis and functionalization of guaianolides, Eur. J. Org. Chem. 10, 2093-2110.

[8] T. Cangiano, M. Della Greca, A. Fiorentino, M. Isidori, P. Monaco and A. Zarrelli (2002). Effect of entlabdane diterpenes from potamogetonaceae on Selenastrum capricornutum and other aquatic organisms, J. Chem. Ecol. 28, 1091-1102.

[9] M. Della Greca, M. Isidori, M. Lavorgna, P. Monaco, L. Previtera and A. Zarrelli (2004). Bioactivity of phenanthrenes from Juncus acutus on Selenastrum capricornutum, J. Chem. Ecol. 30, 867-887.

[10] F. E. Dayan and S. O. Duke, (2014). Natural compounds as next-generation herbicides, Plant Physiol. 166, 1090-1150.

[11] B. D'Abrosca, M. Della Greca, A. Fiorentino, P. Monaco and A. Zarrelli (2004). Low molecular weight phenols from the bioactive aqueous fraction of Cestrum parqui, J. Agr. Food Chem. 52, 4101-4108. 
[12] B. D'Abrosca, M. Della Greca, A. Fiorentino, P. Monaco, A. Natale, P. Oriano and A. Zarrelli (2005). Structural characterization of phytotoxic terpenoids from Cestrum parqui, Phytochemistry 66, 26812688.

[13] D. Stephen, J. Romagni and F. E. Dayan (2000). Natural products as sources for new mechanisms of herbicidal action, Crop Protection. 19, 583-589.

[14] B. D'Abrosca, P. Oriano, A. Golino, A. Izzo, A. Zarrelli and P. Monaco (2007). Lignans, neolignans and sesquilignans from Cestrum parqui l'Her, Biochem. Syst. Ecol. 356, 392-396.

[15] A. Pollio, A. Zarrelli, V. Romanucci, C. Di Mauro, F. Barra, G. Pinto, E. Crescenzi, E. Roscetto and G. Palumbo (2016). Polyphenolic profile and targeted bioactivity of methanolic extracts from Mediterranean ethnomedicinal plants on human cancer cell lines, Molecules 21, 1-23.

[16] G. Di Fabio, V. Romanucci, C. Di Marino, A. Pisanti and A. Zarrelli (2015). Gymnema sylvestre R. Br., an Indian medicinal herb: traditional uses, chemical composition, and biological activity, Curr. Pharm. Biotechnol. 16, 506-516.

[17] A. Zarrelli, V. Romanucci, M. Della Greca, L. De Napoli, L. Previtera and G. Di Fabio (2013). New silybin scaffold for chemical diversification: synthesis of novel 23-phosphodiester silybin conjugates, Syn. Lett. 241, 45-48.

[18] R. Gazak, D. Walterova and V. Kren (2007). Silybin and silymarin-new and emerging applications in medicine, Curr. Med. Chem. 14, 315-338.

[19] D. Csupor, A. Csorba and J. Hohmann (2016). Recent advances in the analysis of flavonolignans of Silybum marianum, J. Pharm. Biomed. Anal. 30, 301-317.

[20] N. Vargas-Mendoza, E. Madrigal-Santillán, Á. Morales-González, J. Esquivel-Soto, C. EsquivelChirino, M. G. L. González-Rubio, J. A. Gayosso-de-Lucio and J. A. Morales-González (2014). Hepatoprotective effect of silymarin, World J. Hepatol. 6, 144-149.

[21] G. Di Fabio, V. Romanucci, C. Di Marino, L. De Napoli and A. Zarrelli (2013). A rapid and simple chromatographic separation of diastereomers of silibinin and their oxidation to produce 2, 3dehydrosilybin enantiomers in an optically pure form, Planta Med. 79, 1077-1080.

[22] V. Romanucci, R. Gravante, M. Cimafonte, C. Di Marino, G. Mailhot, M. Brigante, A. Zarrelli and G. Di Fabio (2017). Phosphate-linked silibinin dimers (PLSd): New promising modified metabolites, Molecules 22, 1323.

[23] A. Zarrelli, A. Sgambato, V. Petito, L. De Napoli, L. Previtera and G. Di Fabio (2011). New C-23 modified of silybin and 2,3-dehydrosilybin: synthesis and preliminary evaluation of antioxidant properties, Bioorg. Med. Chem. Lett. 21, 4389-4392.

[24] A. Zarrelli, V. Romanucci, C. Tuccillo, A. Federico, C. Loguercio, R. Gravante and G. Di Fabio (2014). New silibinin glyco-conjugates: synthesis and evaluation of antioxidant properties, Bioorg. Med. Chem. Lett. 2422, 5147-5149.

[25] S. Trombino, T. Ferrarelli and R. Cassano (2014). A new pro-prodrug aminoacid-based for trans-ferulic acid and silybin intestinal release, J. Funct. Biomater. 5, 99-110.

[26] A. Zarrelli, M. Della Greca, A. Ladhari, R. Haouala and L. Previtera (2013). New triterpenes from Gymnema sylvestre, Helv. Chim. Acta. 966, 1036-1045.

[27] V. Romanucci, C. Agarwal, R. Agarwal, C. Pannecouque, M. Iuliano, G. De Tommaso, T. Caruso, G. Di Fabio and A. Zarrelli (2018). Silibinin phosphodiester glyco-conjugates: Synthesis, redox behaviour and biological investigations, Bioorg. Chem. 77, 349-359.

[28] A. Federico, M. Dallio, C. Tuccillo, C. Loguercio, G. Di Fabio, A. Zarrelli, S. Zappavigna, P. Stiuso and M. Caraglia (2015). Silybin-phosphatidylcholine complex protects human gastric and liver cells from oxidative stress, In Vivo 295, 569-575.

[29] A. Taleb, K. A. Ahmad, A. U. Ihsan, J. Qu, N. Lin, K. Hezam, N. Koju L. Hui and D. Qilong (2018). Antioxidant effects and mechanism of silymarin in oxidative stress induced cardiovascular diseases, Biomed. Pharmacother. 102, 689-698.

[30] G. Di Fabio, V. Romanucci, M. De Nisco, S. Pedatella, C. Di Marino and A. Zarrelli (2013). Microwave-assisted oxidation of silibinin: a simple and preparative method for the synthesis of improved radical scavengers, Tetrahedron Lett. 5446, 6279-6282.

[31] M. F. M. Sciacca, V. Romanucci, A. Zarrelli, I. Monaco, F. Lolicato, N. Spinella, C. Galati, G. Grasso, L. D'Urso, M. Romeo, L. Diomede, M. Salmona, C. Bongiorno, G. Di Fabio, C. La Rosa and D. Milardi (2017). Inhibition of $A \beta$ amyloid growth and toxicity by silybins: The crucial role of stereochemistry, ACS Cheml Neurosci. 88,1767-1778.

[32] P. A. Kevin and A. S. Mahmoud (2013). Free radical scavenging and antioxidant activities of silymarin components, Antioxidants 2, 398-407

[33] B. Mhamdi, F. Abbassi, A. Smaoui, C. Abdelly and B. Marzouk (2016). Fatty acids, essential oil and phenolics composition of Silybum marianum seeds and their antioxidant activities, Pak. J. Pharm. Sci. 29, 951-959. 
[34] N. B. Qin, S. G. Li, X. Y. Yang, C. Gong, X. Y. Zhang, J. Wang, D. H. Li, Y. Q. Guo and H. M. Hua (2017). Bioactive terpenoids from Silybum marianum and their suppression on NO release in LPSinduced BV-2 cells and interaction with iNOS, Bioorg. Med. Chem. Lett. 2710, 2161-2165.

[35] N. H. Al Atraqchi, H. Al Shaikh and M. A. Wafaa (2014). Preliminary phytochemical screening and invitro evaluation of antioxidant activity of iraqi species of Silybum marianum seeds, Int. Res. J. Pharmacy. 5, 378-383.

[36] E. Ahmed, A. Malik, S. Ferheen, N. Afza, M. A. Lodhi and M. I. Choudhary (2006). Chymotrypsin inhibitory triterpenoids from Silybum marianum, Chem. Pharm. Bull. 541, 103-106.

[37] E. Ahmed, A. Malik, S. Ferheen and N. Afza (2007). Structural determination of silymins A and B, new pentacyclic triterpenes from Silybum marianum, by 1D and 2D NMR spectroscopy, Magn. Reson. Chem. 451, 79-81.

[38] E. Ahmed, A. Malik, M. A. Munawar, S. A. Nagra, M. M. Ahmed, J. Anwar, M. A. Qazi, A. Sharif, N. Afza and M. Ashraf (2008). Antifungal and antioxidant constituents from Silybum mariarum, J. Chem. Soc. Pak. 306, 942-949.

[39] S. A. Ismaili, H. Harhar and S. Gharby (2016). Chemical composition of two non-conventional oils in Morocco: Melia azadirachta and Silybum marianum L., J. Mater. Environ. Sci. 76, 2208-2213.

[40] S. A. Ismaili, K. Sayah, H. Harhar, M. E. A. Faouzi, S. Gharby, B. Himmi, S. Kitane and M. A. El Belghiti (2016b). Chemical analysis and anti-oxidation activities of the Moroccan milk thistle, Mor. J. Chem. 43, 4-13.

[41] K. H. Pegel (1997). The importance of sitosterol and sitosterolin in human and animal nutrition, S. Afr. J. Sci. 93, 263-268.

[42] C. S. Chambers, V. Holečková, L. Petrásková, D. Biedermann, K. Valentová, M Buchta and V. Křen (2017). The silymarin composition and why does it matter?, Food Res. Int. 100, 339-353.

[43] ISO 6799. Determination of the sterol fraction by gas chromatography.

[44] B. Fathi-Achachlouei and S. Azadmard-Damirchi (2009). Milk thistle seed oil constituents from different varieties grown in Iran, J. Am. Oil Chem. Soc. 867, 643-649.

[45] M. H. El-Mallah, S.M. El-Shami and M. M. Hassanein (2003). Detailed studies on some lipids of Silybum marianum L. seed oil, Grasas Aceites 544, 397-402.

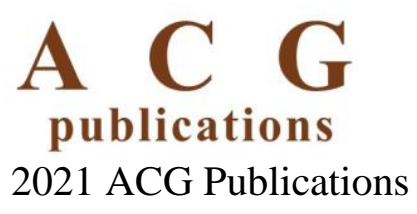

